\title{
Evaluation of trace element availability from secondary metallurgical slag generated in steelmaking by sequential chemical extraction
}

\author{
M. Mäkelä • I. Välimäki • R. Pöykiö • \\ H. Nurmesniemi · O. Dahl
}

Received: 15 November 2011 / Revised: 1 July 2012/ Accepted: 23 December 2012/Published online: 26 February 2013

(C) Islamic Azad University (IAU) 2013

\begin{abstract}
During carbon steel manufacture, slag residues are generated to remove material impurities from liquid metal and thus control the quality of carbon steel. As the utilization of secondary metallurgical slags is not as efficient as those of primary slags, a comprehensive characterization of steel ladle slag was performed. Pseudo-total concentrations of a wide range of elements were determined during a 6-week sampling period with relevant physical and chemical properties, sequential extraction of trace elements, and parallel mineralogical characterization of extraction residues from a representative combined sample. According to the results, only $\mathrm{Cr}$ and $\mathrm{V}$ occurred in elevated concentrations with respective 6-week mean values of 198 and $310 \mathrm{mg} \mathrm{kg}^{-1}$ (d.w.). The residual standard
\end{abstract}

Electronic supplementary material The online version of this article (doi:10.1007/s13762-012-0160-5) contains supplementary material, which is available to authorized users.

M. Mäkelä $(\varangle) \cdot$ O. Dahl

Department of Forest Products Technology,

School of Chemical Technology,

Aalto University, P.O. Box 16400,

Tekniikantie 3, 00076 Aalto, Finland

e-mail: mmaekelae@gmail.com

I. Välimäki

Suomen Ympäristöpalvelu Oy,

Sammonkatu 8, 90570 Oulu, Finland

R. Pöykiö

City of Kemi, Valtakatu 26,

94100 Kemi, Finland

H. Nurmesniemi

Stora Enso Oyj, Veitsiluoto Mill,

94830 Kemi, Finland deviation of the weekly pseudo-total concentration values of the aforementioned elements (24 and $31 \%$, respectively) indicated that significant variation in the concentration of trace elements can occur due to fluctuation in process conditions and/or slag characteristics. The sequential extraction procedure suggested potential phytoavailability of $\mathrm{V}\left(123 \mathrm{mg} \mathrm{kg}^{-1}\right.$, d.w., amounting to $41 \%$ of the respective pseudo-total concentration) through, e.g., changes in prevailing redox conditions. Although the analytical approach was validated by the analysis of a certified reference material and the calculation of extraction recoveries, the mineralogical characterization of parallel extraction residues indicated non-selectivity of the procedure coupled with potential redistribution phenomena during extraction with hydrogen peroxide and ammonium acetate.

Keywords Certified reference material - Fractionation Ladle slag $\cdot$ X-ray diffraction

\section{Introduction}

Conventional carbon steel manufacture from virgin ore is generally managed through the blast furnace/basic oxygen furnace-process route (Cottrell 1975). The main objective of these processes is to attain an efficient reduction degree of iron ore to crude iron, to remove material impurities, and to adjust the level of carbon, one of the most effective alloying elements of steel. To remove impurities from liquid metal, lime is generally used to generate a separate slag phase, which can be effectively decoupled from the desired product. Alkalis, such as sodium and potassium, sulfur, phosphorus or trace elements, such as arsenic, copper, chromium, lead, nickel, or vanadium, can have 
undesired effects on the operation of the blast furnace or the quality of carbon steel. During secondary metallurgy, the quality of liquid steel is finalized in a ladle prior to casting. Fluxing agents, such as calcium aluminate or calcium fluoride, are admixed to the ladle producing an average of $30 \mathrm{~kg}$ of ladle slag per metric ton of steel produced (Manso et al. 2005; Shi and Hu 2003). As opposed to primary blast furnace and basic oxygen furnace slags, the utilization of secondary steel ladle slag is not as efficient and is often sent to landfill.

To evaluate the use potential of ladle slag and possible effects due to current landfilling procedure, the physical and chemical characteristics of the material and certain parameters with possible adverse environmental impacts upon utilization, such as trace element content and respective availability, have to be known. In the field of metals processing from virgin ore, this is further emphasized by the expected decline in ore quality, which will have an effect in the trace element content of respective processing residuals. As the total concentrations of trace elements are generally insufficient in describing possible biological effects (Zufiaurre et al. 1998), chemical speciation is often used in identifying and quantifying the different species, forms, or phases present in a solid material (Filgueiras et al. 2002). As a tool for chemical speciation, operationally defined sequential extraction procedures apply various successive extractions on a sample with an aim to divide the total extractable concentration of an element into separate fractions to assess the potential forms in which the element occurs in the material (Manskinen et al. 2011). Although time consuming and mainly hypothetical, the use of a sequential extraction procedure is generally a good compromise for attaining information on the risk of environmental contamination in support of environmental policy (Kazi et al. 2005; Pueyo et al. 2001).

As sequential extraction procedures have been implemented since the well-known work of Tessier et al. (1979), no single procedure to date has been unreservedly accepted by the scientific community (Fuentes et al. 2004). However, the three-step BCR (The European Community Bureau of Reference, now the Standards, Measurement and Testing programme) procedure proposed by the European Community in 1993 and revised by Rauret et al. (1999), although originally developed for sediments, has been applied for a wide range of solid samples including industrial residues such as ashes and mining wastes (Anju and Banerjee 2010; Marguí et al. 2004; Nurmesniemi et al. 2008; Smeda and Zyrnicki 2002). As opposed to the scheme of Tessier et al. (1979), the main intention of the BCR procedure lies in simulating the various possible natural and anthropogenic modifications of prevailing environmental conditions (Gleyzes et al. 2002; Ryan et al. 2008). However, although a large body of literature supports the implementation of the
$\mathrm{BCR}$ procedure on various environmental media, the main drawbacks of sequential extraction such as lack of additional data regarding selectivity, occurrence of redistribution and readsorption, methodological and interpretive issues, and tediousness of the procedures (Bacon and Davidson 2008; Gleyzes et al. 2002; Jamali et al. 2009; Martínez-Fernández et al. 2011; Rao et al. 2008) remain valid also in the case of the BCR procedure. In addition, in the case of slag materials, concern regarding the suitability of sequential extraction was reported by Dahlin et al. (2002). According to the authors, increased non-selectivity of sequential extraction procedures originally designed for sediment and soil extractions could occur due to a relatively higher level of individual pollutant particles encapsulated by the sample matrix.

As information on the relevant characteristics of secondary slag materials from carbon steel manufacture is limited, a comprehensive characterization study on ladle slag was performed. Pseudo-total concentrations of a widerange of elements were determined during the course of a 6-week sampling program. Relevant physical and chemical properties with easily available plant nutrient concentrations were determined from a representative combined sample. In addition, trace element availability was investigated using the revised $\mathrm{BCR}$ sequential extraction procedure with parallel mineralogical observations by X-ray diffraction (XRD). As trace element availability can primarily be regarded as a function of the mineralogy and solid fraction chemistry of the sample (Ryan et al. 2008), additional X-ray-based analytical methods have been deemed necessary to identify remaining sample components during sequential extraction (Bacon and Davidson 2008). Based on available literature, a similar approach for the mineralogical characterization of BCR residues of secondary metallurgical slag has not been published before. The objective was (1) to contribute to the availability of information regarding metallurgical residues and, (2) to investigate the potential of the BCR method in the respective context.

\section{Materials and methods}

Sampling and sample preparation

A 6-week sampling program was performed to evaluate the variation of ladle slag properties. A weekly sample of approximately $9 \mathrm{~kg}$ (ca. $20 \mathrm{dm}^{3}$ ) was collected on consecutive weeks from the slag pit of the respective industrial facility. The weekly samples were gathered with a steel shovel from various points of a slag pile representing metal-separated slag generated during the week and sealed in $10-\mathrm{dm}^{3}$ polyethylene containers. The individual samples 
were processed twice with a spinning riffler to one-eighth of the input to attain a subsample of approximately $150 \mathrm{~g}$. From the weekly subsamples, $10 \pm 0.5$ and $3 \pm 0.5 \mathrm{~g}$ were, respectively, preserved for pseudo-total element concentration determinations and scanning electron microscopy (SEM). Subsequently, the subsamples were combined, and the combined sample processed again with the spinning riffler to attain a 6-week representative combined sample of approximately $135 \mathrm{~g}$ for the determination of relevant physical and chemical properties, easily available plant nutrient concentrations, and sequential extraction of trace elements with respective mineralogical analysis.

Determination of relevant physical and chemical properties, easily soluble plant nutrient concentrations, and SEM observations

Electrical conductivity (EC) and $\mathrm{pH}$ were determined from the combined sample at a solid-to-liquid (i.e., ultrapure water) ratio of $1: 2.5(\mathrm{v} / \mathrm{v})$ with a combined $\mathrm{EC} / \mathrm{pH}$ analyzer equipped with a Phoenix conductivity electrode (Phoenix Electrode Co., Texas, USA) and a Thermo Orion SureFlow pH electrode (Thermo Fisher Scientific, Beverly, USA). The dry matter content was determined according to international standard SFS-ISO 11465 by drying the sample overnight to a constant mass at a temperature of $105{ }^{\circ} \mathrm{C}$. The determination of loss on ignition (LOI) value was performed according to European standard SFS-EN 12879 , in which an oven-dried $\left(105^{\circ} \mathrm{C}\right)$ sample is drydigested overnight in a muffle furnace (Naberthem, Germany) at a temperature of $550{ }^{\circ} \mathrm{C}$. The total organic carbon (TOC) content was determined according to European standard SFS-EN 13137 by combusting the sample and measuring the evolved carbon dioxide by infrared spectroscopy with a LECO CHN-600 analyzer (Leco Corp., Michigan, USA). The neutralizing value (NV) determination was performed according to European standard SFS-EN 12945, in which the NV is determined by back titration with sodium hydroxide from a solution of a specific quantity of standard hydrochloric acid and a dried sample. The reactivity value (RV) determination was performed according to European standard SFS-EN 13971, in which the carbonates are determined by potentiometric titration with hydrochloric acid. In addition, easily soluble plant nutrient ( $\mathrm{Ca}, \mathrm{Mg}, \mathrm{Na}, \mathrm{K}, \mathrm{P}, \mathrm{S}, \mathrm{Cu}, \mathrm{Zn}$, and $\mathrm{Mn}$ ) concentrations were determined from the combined sample by extraction with $0.5 \mathrm{~mol} \mathrm{~L}{ }^{-1}$ acidic ammonium acetate (pH 4.65: $\mathrm{Ca}, \mathrm{Mg}, \mathrm{Na}, \mathrm{K}, \mathrm{P}, \mathrm{S}$ ) or ammonium acetate coupled with $0.02 \mathrm{~mol} \mathrm{~L}^{-1}$ ethylenediaminetetra-acetic acid disodium salt $\left(\mathrm{Na}_{2}\right.$ EDTA: $\left.\mathrm{Cu}, \mathrm{Mn}, \mathrm{Zn}\right)$ according to the procedure by Yli-Halla and Palko (1987). Secondary electron images were taken from the weekly subsamples with a LEO 1450 secondary electron microscope (LEO Electron Microscopy Ltd., Cambridge, UK) with an acceleration voltage of $12 / 15 \mathrm{kV}$. Prior to analysis, the powdery samples were attached to bilateral carbon tape and gold-plated with ca. $15 \mathrm{~nm} \mathrm{Au}$.

Extraction of trace elements and mineralogical characterization of extraction residues

For investigating trace element availability, the revised four-stage BCR procedure outlined in Table 1 was used. The procedure has been widely applied for the fractionation of trace elements in various environmental matrices, including mining waste, ash, sludge, soil, and sediment (Anju and Banerjee 2010; Bacon and Davidson 2008; Marguí et al. 2004; Nemati et al. 2010; Nurmesniemi et al. 2008; Smeda and Zyrnicki 2002). Strict adherence to the revised procedure recommended by Pueyo et al. (2001) was maintained during the entire procedure and is presented to guarantee compliance with the protocol; all glass and plastic ware were acid washed prior to use, reverse osmosis and ion-exchange (Elgastat Prima and Maxima, Elga Ltd., Bucks, Great Britain) purified water (resistivity $18 \mathrm{M} \Omega \mathrm{cm}^{-1}$ ) was used in the preparation of reagent solutions, a mechanical end-over-end shaker at $30 \mathrm{rpm}$ was used for all extractions, and the attained extracts and solid residues were separated by centrifugation at 3,000 rpm for $20 \mathrm{~min}$. The resulting supernatant liquids were decanted into polyethylene containers which were stored at $4{ }^{\circ} \mathrm{C}$ until element concentration determinations. Excluding $\mathrm{Hg}$, pseudo-total element concentrations in the extracts were determined with a Thermo Fisher Scientific iCAP6500 Duo (Thermo Fisher Scientific Inc., Cambridge, UK) inductively coupled plasma optical emission spectrometer (ICPOES) equipped with a Cetac ASX-520 autosampler (Cetac Technologies, Nebraska, USA). In the case of $\mathrm{Hg}$, pseudototal concentration was determined with a PerkinElmer AAnalyst 700 cold vapour atomic absorption spectrometer (CVAAS) equipped with a PerkinElmer FIAS 400 and AS 90 plus autosampler (PerkinElmer, Norwalk, USA). For ICP-OES and CVAAS operating conditions, see Tables 2 and 3. Calibration standards for ICP-OES determinations were generated by serial dilution of the following AccuStandard (AccuStandard Corp., AccuTrace ${ }^{\circledR}$, New Haven, USA) multielement stock solutions:

(i) Custom ICP standard 1 (IS-15239A-R1) containing $1,000 \mathrm{mg} \mathrm{L}^{-1} \mathrm{Al}, \mathrm{Fe}, \mathrm{K}, \mathrm{P}, \mathrm{Ca} ; 500 \mathrm{mg} \mathrm{L}^{-1} \mathrm{~S}, \mathrm{Mg}$, $\mathrm{Na}$, and $\mathrm{Ti}$;

(ii) Custom ICP standard 2 (IS-15239B) containing $400 \mathrm{mg} \mathrm{L}^{-1} \mathrm{Ba}, \mathrm{Mn}, \mathrm{Zn}, \mathrm{Pb} ; 200 \mathrm{mg} \mathrm{L}^{-1} \mathrm{Cr}, \mathrm{Cu}$, $\mathrm{Ni}, \mathrm{V} ; 100 \mathrm{mg} \mathrm{L}^{-1} \mathrm{As}, \mathrm{Cd}, \mathrm{Co}, \mathrm{Sb} ; 50 \mathrm{mg} \mathrm{L}^{-1} \mathrm{~B}$, Be, Se, Mo, and Sn. 
Table 1 Chemical reagents used in the revised four-stage BCR extraction procedure for investigating trace element availability from the combined ladle slag sample

\begin{tabular}{|c|c|c|}
\hline Step & Reagents & $\begin{array}{l}\text { Description (nominal target } \\
\text { phases) }\end{array}$ \\
\hline 1 & $\begin{array}{l}40 \mathrm{~mL} \text { acetic acid } \\
\left(0.11 \mathrm{~mol} \mathrm{~L}^{-1}\right)\end{array}$ & $\begin{array}{l}\text { Exchangeable, acid-soluble } \\
\text { (exchangeable cations and } \\
\text { carbonates) }\end{array}$ \\
\hline 2 & $\begin{array}{l}40 \mathrm{~mL} \text { hydroxylamine } \\
\text { hydrochloride }\left(0.5 \mathrm{~mol} \mathrm{~L}^{-1} \text {; }\right. \\
25 \mathrm{~mL} 2 \mathrm{~mol} \mathrm{~L} \mathrm{~L}^{-1} \\
\left.\mathrm{HNO}_{3} \mathrm{~L}^{-1}\right)\end{array}$ & $\begin{array}{l}\text { Easily reducible (iron/ } \\
\text { manganese oxyhydroxides) }\end{array}$ \\
\hline 3 & $\begin{array}{l}10 \mathrm{~mL} \text { hydrogen peroxide } \\
\left(8.8 \mathrm{~mol} \mathrm{~L}^{-1}\right), \\
50 \mathrm{~mL} \text { ammonium acetate } \\
\left(1 \mathrm{~mol} \mathrm{~L}^{-1} ; \text { adjusted to } \mathrm{pH}\right. \\
\left.2 \text { with } \mathrm{HNO}_{3}\right)\end{array}$ & $\begin{array}{l}\text { Oxidizable (organic matter } \\
\text { and sulfides) }\end{array}$ \\
\hline 4 & $\begin{array}{l}9 \mathrm{~mL} \text { hydrochloric acid } \\
\left(12.0 \mathrm{~mol} \mathrm{~L}^{-1}\right)+3 \mathrm{~mL} \\
\text { nitric acid }\left(15.8 \mathrm{~mol} \mathrm{~L} \mathrm{~L}^{-1}\right) \\
\text { microwave digestion }\end{array}$ & Residual \\
\hline
\end{tabular}

Table 2 Operating conditions of ICP-OES and FI-CVAAS

\begin{tabular}{|c|c|c|c|}
\hline \multicolumn{2}{|l|}{ ICP-OES } & \multicolumn{2}{|c|}{ FI-CVAAS (Hg) } \\
\hline RF power & $1,150 \mathrm{~W}$ & Pump rate & $120 \mathrm{rpm}$ \\
\hline Coolant gas flow & $12 \mathrm{~L} \mathrm{~min}^{-1}$ & Reductant & $\mathrm{SnCl}_{2}$ \\
\hline Auxiliary gas flow & $0.5 \mathrm{~L} \mathrm{~min}^{-1}$ & $\begin{array}{l}\text { Carrier } \\
\text { solution }\end{array}$ & $\begin{array}{c}3 \%(\mathrm{v} / \mathrm{v}) \\
\mathrm{HCl}\end{array}$ \\
\hline Nebulizer gas flow & $0.60 \mathrm{~L} \mathrm{~min}^{-1}$ & Carrier gas & $\operatorname{Ar}(5.0)$ \\
\hline Flush pump rate & $50 \mathrm{rpm}$ & $\begin{array}{l}\text { Quartz tube } \\
\text { temperature }\end{array}$ & $100{ }^{\circ} \mathrm{C}$ \\
\hline Analysis pump rate & $50 \mathrm{rpm}$ & $\begin{array}{l}\text { Injection } \\
\text { volume }\end{array}$ & $500 \mu \mathrm{l}$ \\
\hline Nebulizer & $\begin{array}{l}\text { Glass } \\
\text { concentric }\end{array}$ & $\begin{array}{c}\text { Background } \\
\text { correction }\end{array}$ & $D_{2}$ \\
\hline Spray chamber & Glass cyclonic & Lamp/current & $\begin{array}{l}\text { EDL/ } \\
130 \mathrm{~mA}\end{array}$ \\
\hline Center tube & $2 \mathrm{~mm}$ & Wavelength & $253.7 \mathrm{~nm}$ \\
\hline Integration times & $5 \mathrm{~s}$ & Slit width & $0.7 \mathrm{~nm}$ \\
\hline Replicates & 2 & $\begin{array}{l}\text { Signal } \\
\text { measurement }\end{array}$ & $\begin{array}{l}\text { Peak } \\
\text { height }\end{array}$ \\
\hline Rinse time & $15 \mathrm{~s}$ & Read time & $15 \mathrm{~s}$ \\
\hline Sample flush time & $40 \mathrm{~s}$ & Read delay & $0 \mathrm{~s}$ \\
\hline Emission lines & See Table 3 & BOC time & $2 \mathrm{~s}$ \\
\hline $\begin{array}{l}\text { Measurement modes } \\
\text { (plasma view) }\end{array}$ & $\begin{array}{l}\text { Axial/radial, } \\
\text { see Table } 3\end{array}$ & Replicates & 2 \\
\hline
\end{tabular}

Second source quality control standards were generated of similar custom-made calibration mixes manufactured by SPEX CertiPrep Corp. (SPEX CertiPrep Corp. Metuchen, NJ, USA). Calibration standards for CVAAS determinations were manufactured from $1,000 \mathrm{mg} \mathrm{L}^{-1} \mathrm{Hg}$ single
Table 3 ICP-OES emission lines (backup emission lines in parentheses) and modes of measurement

\begin{tabular}{|c|c|c|c|}
\hline Element & $\begin{array}{l}\text { Emission line } \\
(\mathrm{nm})\end{array}$ & Element & $\begin{array}{l}\text { Emission } \\
\text { line }(n m)\end{array}$ \\
\hline $\begin{array}{l}\mathrm{Al} \text { (high } \\
\text { concentrations) }\end{array}$ & 308.215 I radial & $\begin{array}{l}\text { Mn (high } \\
\text { concentrations) }\end{array}$ & $\begin{array}{l}257.610 \\
\text { II radial }\end{array}$ \\
\hline $\begin{array}{l}\mathrm{Al} \text { (low } \\
\text { concentrations) }\end{array}$ & 396.152 I axial & $\begin{array}{l}\text { Mn (low } \\
\text { concentrations) }\end{array}$ & $\begin{array}{l}257.610 \\
\text { II axial }\end{array}$ \\
\hline As & $\begin{array}{l}189.042 \text { I axial } \\
(193.759 \text { I } \\
\text { axial })\end{array}$ & Mo & $\begin{array}{r}202.030 \\
\text { II axial } \\
(203.844 \\
\text { II axial })\end{array}$ \\
\hline B & 208.959 I axial & $\mathrm{Na}$ & $\begin{array}{l}589.592 \text { I } \\
\text { radial }\end{array}$ \\
\hline $\mathrm{Ba}$ & 455.403 II radial & $\mathrm{Ni}$ & $\begin{array}{l}231.604 \\
\text { II axial }\end{array}$ \\
\hline $\mathrm{Be}$ & 313.042 II radial & $\mathrm{P}$ & $\begin{array}{l}185.942 \mathrm{I} \\
\text { axial }\end{array}$ \\
\hline $\mathrm{Ca}$ & 317.933 II radial & $\mathrm{Pb}$ & $\begin{array}{r}220.353 \\
\text { II axial } \\
(216.999 \\
\text { I axial })\end{array}$ \\
\hline $\mathrm{Cd}$ & $\begin{array}{l}228.802 \text { I axial } \\
(214.438 \text { II } \\
\text { axial })\end{array}$ & S & $\begin{array}{l}182.034 \mathrm{I} \\
\text { axial }\end{array}$ \\
\hline Co & 228.616 II axial & $\mathrm{Sb}$ & $\begin{array}{l}206.833 \text { I } \\
\text { axial } \\
(217.581 \\
\text { I axial })\end{array}$ \\
\hline $\mathrm{Cr}$ & $\begin{array}{l}267.716 \text { II axial } \\
(283.563 \text { II } \\
\text { axial) }\end{array}$ & $\mathrm{Se}$ & $\begin{array}{l}196.090 \mathrm{I} \\
\text { axial }\end{array}$ \\
\hline $\mathrm{Cu}$ & 324.754 I radial & Sn & $\begin{array}{c}189.989 \\
\text { II axial }\end{array}$ \\
\hline $\begin{array}{l}\mathrm{Fe} \text { (high } \\
\text { concentrations) }\end{array}$ & 259.940 II radial & $\mathrm{Ti}$ & $\begin{array}{l}336.121 \\
\text { II radial }\end{array}$ \\
\hline $\begin{array}{l}\text { Fe (low } \\
\text { concentrations) }\end{array}$ & 259.940 II axial & V & $\begin{array}{l}292.402 \\
\text { II radial }\end{array}$ \\
\hline K & 766.491 I radial & $\mathrm{Zn}$ & $\begin{array}{l}206.200 \\
\text { II axial }\end{array}$ \\
\hline $\mathrm{Mg}$ & 285.213 I radial & & \\
\hline
\end{tabular}

element stock solution (AccuStandard Corp., AccuTrace ${ }^{\circledR}$, New Haven, USA). In order to obtain careful matrix matching of the calibration standards and samples, calibration solutions were fashioned with the same extracting solution that was used during sample preparation. In case the element concentrations could not be determined immediately, $200 \mu \mathrm{L} 65 \%$ nitric acid (Suprapur, Merck, Darmstadt, Germany) was added to minimize precipitation. The attained solid residues from centrifugation were washed with $20-\mathrm{mL}$ distilled water by shaking in the endover-end shaker for $15 \mathrm{~min}$ and centrifuged at 3,000 rpm for $20 \mathrm{~min}$. Subsequently, the supernatant was decanted 
and discarded. In addition to the combined slag sample, a certified reference material (CRM) BCR-701 representing the sediment from Lake Orta, Piemonte, Italy was purchased from the Institute for Reference Materials and Measurements (IRMM, Geel, Belgium) and analyzed according to the following steps 1-4 to provide information on quality control (Pueyo et al. 2001, 2008; Sutherland 2010).

Step 1: 40-mL acetic acid (prepared from $100 \%$ $\mathrm{CH}_{3} \mathrm{COOH}$, Baker Analyzed, J.T. Baker, Deventer, The Netherlands) was added to $1 \mathrm{~g}$ of the combined sample in a $100-\mathrm{mL}$ centrifuge tube and shaken at room temperature overnight for $16 \mathrm{~h}$. The solid residue and supernatant were separated by centrifugation and decantation, and the solid residue washed as previously described.

Step 2: 40-mL hydroxylamine hydrochloride (prepared from $>99 \% \mathrm{NH}_{2} \mathrm{OH} \cdot \mathrm{HCl}$, Merck, Darmstadt, Germany) was added to the residue from step 1 in the centrifuge tube and shaken at room temperature overnight for $16 \mathrm{~h}$. The solid residue and supernatant were separated by centrifugation and decantation, and the solid residue washed as per step 1.

Step 3: 10-mL hydrogen peroxide (30\%, Baker Analyzed, J.T. Baker, Deventer, The Netherlands) was added to the residue from step 2 in the centrifuge tube. The tube was loosely covered and digested at room temperature for $1 \mathrm{~h}$ with occasional manual shaking followed by digestion at $85 \pm 2{ }^{\circ} \mathrm{C}$ for $1 \mathrm{~h}$ in a water bath with occasional manual shaking for the first half hour. Subsequently, the tube was uncovered and further heated to reduce the volume of the liquid phase to approximately $2.5 \mathrm{~mL}$. A further $10 \mathrm{~mL}$ of hydrogen peroxide (Table 1) was added to the centrifuge tube and the digestion continued with the cover on at $85 \pm 2{ }^{\circ} \mathrm{C}$ for $1 \mathrm{~h}$ with occasional manual shaking for the first half hour. The cover was then removed and volume of the liquid phase reduced to approximately $1 \mathrm{~mL}$. After the residue was cooled, 50-mL ammonium acetate (prepared from $>97 \%$ $\mathrm{CH}_{3} \mathrm{COONH}_{4}$, Baker Analyzed, J.T. Baker, Deventer, The Netherlands) was added to the mixture and shaken at room temperature overnight for $16 \mathrm{~h}$. The solid residue and supernatant were then separated by centrifugation and decantation, and the solid residue washed as per step 1.

Step 4: a mixture of 9-mL hydrochloric (30\%, Suprapur, Merck, Darmstadt, Germany) and 3-mL nitric acid (65\%, Suprapur, Merck, Darmstadt, Germany) (Table 1) was added to the residue from step 3 and directly to the combined base sample and the weekly $10 \pm 0.5 \mathrm{~g}$ subsamples and the mixtures digested in a CEM Mars 5 microprocessor controlled microwave oven for $10 \mathrm{~min}$ at a temperature of $175^{\circ} \mathrm{C}$ with CEM HP 500 Teflon vessels (CEM Corp., Matthews, USA). The cooled solution was transferred to a $100-\mathrm{mL}$ volumetric flask and the solution diluted to volume with ultrapure water.
To monitor the mineralogy of the combined slag sample during sequential extraction, a total of ten parallel extractions were performed on the combined sample and the mineralogy of the base sample and successive fraction residues of the procedure were analyzed with XRD. Prior to the analysis, the residues from the sequential extraction steps were air-dried in polypropylene measuring cylinders at a temperature of $40{ }^{\circ} \mathrm{C}$ to ascertain minimum alteration of sample structure. Subsequently, the remaining samples were treated with approximately $0.5-\mathrm{mL}$ ethanol (Etax A14, Altia, Rajamäki, Finland) and homogenized in agate mortars and spread on glass plates to enable the evaporation of ethanol. The following measurements were performed on a Philips PW 3040 X'Pert MPD X-ray diffractometer (PANanalytical B.V., Almelo, The Netherlands) with Co-K $\alpha$ radiation (wavelength $1.78897 \AA$ ) and an iron filter. An iron filter was installed as the diffractometer is frequently used in attaining information on the mineralogy of a wide variety of slag samples from steelmaking. The diffractometer was operated on an acceleration voltage of $45 \mathrm{kV}$ and a current of $40 \mathrm{mV}$. The measurement range was set to $5^{\circ}-100^{\circ}(2 \theta)$ with $0.04 / 1 \mathrm{~s}$. A visual interpretation of the experimental regime from sampling to sequential extraction and respective XRD analyses of parallel extractions is illustrated in Fig. 1.

\section{Results and discussion}

Relevant physical and chemical properties, easily soluble plant nutrient concentrations, and SEM observations

The average physical and chemical properties and easily available plant nutrient concentrations of ladle slag based on the combined sample are presented in Table 4 on a dry weight (d.w.) basis. The characteristics were determined in duplicate mainly to provide background information for the performed extractions, and the standard deviations are thus not included. According to these results, the slag material is alkaline and inorganic by nature. The EC value $\left(4.24 \mathrm{mS} \mathrm{cm}^{-1}\right)$, which is an index of the total dissolved electrolyte concentrations, indicates that the leachate of the slag sample had a relatively low ionic strength, and hence only a minor part of the dissolved metals occurred as dissolved basic metal salts (Manskinen et al. 2011). The LOI and TOC values ( 6.6 and $<2 \%$, respectively) support the inexistence of organic carbon, although the LOI value can only be regarded as an indirect measure of organic contents. Even though the LOI parameter is frequently used in waste characterization studies in quantifying the content of organic matter, additional reactions to organic matter decomposition, such as dehydration of metal oxides, loss of 
Fig. 1 The experimental regime from sampling to sequential extraction and respective XRD analyses of parallel extractions

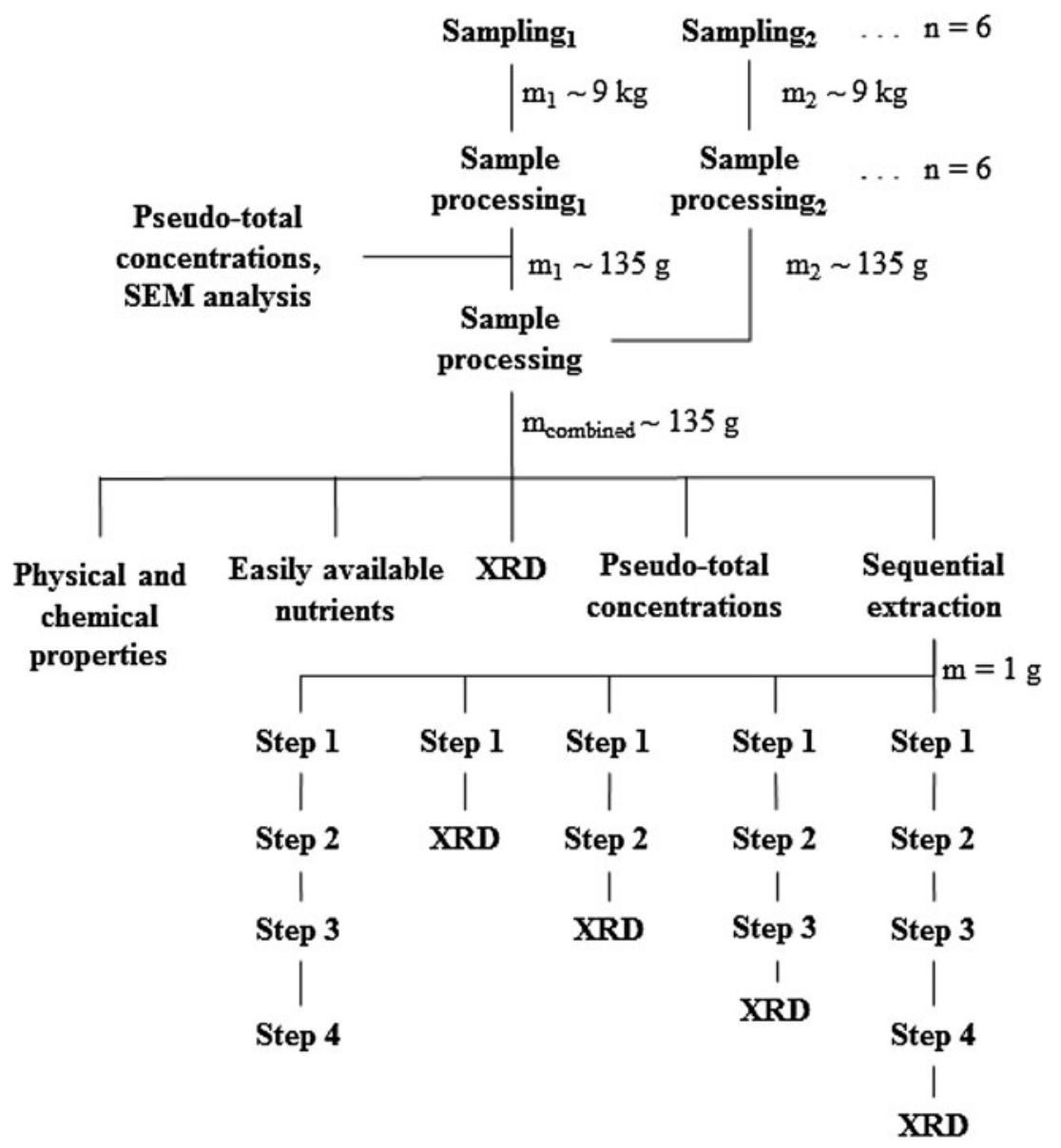

Northern Finland; enrichment values for $\mathrm{P}, \mathrm{Ca}, \mathrm{Mg}, \mathrm{K}, \mathrm{Na}$, $\mathrm{S}, \mathrm{Cu}, \mathrm{Mn}$, and $\mathrm{Zn}$ were calculated based on Manskinen et al. (2011) and are presented in Table 4. According to the results, ladle slag contains significantly higher concentrations of $\mathrm{Ca}, \mathrm{Mg}, \mathrm{K}, \mathrm{Na}, \mathrm{S}$, and $\mathrm{Mn}$, and lower concentrations of $\mathrm{Cu}$ and $\mathrm{Zn}$ than average Northern Finnish local coarse mineral soil. Elevated concentrations of $\mathrm{Na}$ and $\mathrm{S}$ in the slag sample are reasonable as these elements are detrimental in steelmaking processes and are managed from the raw materials to the generated slag phases.

Acquired SEM images of weekly ladle slag samples are provided in Fig. 2. Evidently, the slag samples possessed an angular-like morphology, with two distinct size fractions of approximately 100 and $1-10 \mu \mathrm{m}$ in diameter. The divergence regarding the observed size fractions could be explained by the temperature decrease induced phase transformations commonly occurring in calcium silicate slag materials (Shi and $\mathrm{Hu}$ 2003). As an example, the larnite phase $\left[\mathrm{Ca}_{2} \mathrm{SiO}_{4}\right]$ generally found in calcium silicate slags undergoes a phase transformation from $\alpha^{\prime}-\mathrm{Ca}_{2} \mathrm{SiO}_{4}$ to $\beta-\mathrm{Ca}_{2} \mathrm{SiO}_{4}$ at a temperature above $775{ }^{\circ} \mathrm{C}$ and a further conversion to $\gamma-\mathrm{Ca}_{2} \mathrm{SiO}_{4}$ at a temperature range of 
Table 4 Relevant physical and chemical properties with easily soluble plant nutrient concentrations and enrichment values (R) of ladle slag determined from the combined 6-week sample

\begin{tabular}{|c|c|c|c|}
\hline Parameter & Unit & $\begin{array}{l}\text { Ladle } \\
\text { slag }\end{array}$ & $R^{\mathrm{a}}$ \\
\hline $\mathrm{pH}(1: 5)$ & & 11.7 & \\
\hline Electrical conductivity (EC; 1.2 .5$)$ & $\mathrm{mS} \mathrm{cm} \mathrm{cm}^{-1}$ & 4.24 & \\
\hline Dry matter content $\left(105^{\circ} \mathrm{C}\right)$ & $\%$ & 99.4 & \\
\hline Loss on ignition (LOI; $550{ }^{\circ} \mathrm{C}$ ) & $\%$ (d.w.) & 6.6 & \\
\hline Total organic carbon (TOC) & $\mathrm{mg} \mathrm{kg}^{-1}$ (d.w.) & $<2$ & \\
\hline Neutralizing value & $\%$ (Ca; d.w.) & 32.4 & \\
\hline Reactivity value & $\%$ (Ca; d.w.) & 31.6 & \\
\hline $\mathrm{P}^{\mathrm{b}}$ & $\mathrm{mg} \mathrm{kg}^{-1}$ (d.w.) & $<2$ & \\
\hline $\mathrm{Ca}^{\mathrm{b}}$ & $\mathrm{mg} \mathrm{kg}^{-1}$ ) (d.w.) & 88,200 & 91.9 \\
\hline $\mathrm{Mg}^{\mathrm{b}}$ & $\mathrm{mg} \mathrm{kg}^{-1}$ (d.w.) & 8,100 & 60.0 \\
\hline $\mathrm{K}^{\mathrm{b}}$ & $\mathrm{mg} \mathrm{kg}^{-1}$ (d.w.) & 510 & 6.6 \\
\hline $\mathrm{Na}^{\mathrm{b}}$ & $\mathrm{mg} \mathrm{kg}^{-1}$ (d.w.) & 220 & 22.0 \\
\hline $\mathrm{S}^{\mathrm{b}}$ & $\mathrm{mg} \mathrm{kg}^{-1}$ (d.w.) & 500 & 21.7 \\
\hline $\mathrm{Cu}^{\mathrm{c}}$ & $\mathrm{mg} \mathrm{kg}^{-1}$ (d.w.) & 2.3 & 0.7 \\
\hline $\mathrm{Mn}^{\mathrm{c}}$ & $\mathrm{mg} \mathrm{kg}^{-1}$ (d.w.) & 680 & 24.3 \\
\hline $\mathrm{Zn}^{\mathrm{c}}$ & $\mathrm{mg} \mathrm{kg}^{-1}$ (d.w.) & 2.1 & 0.6 \\
\hline \multicolumn{4}{|l|}{$n=2$} \\
\hline \multicolumn{4}{|c|}{$\begin{array}{l}\text { a } R=(\text { concentration in ladle slag }) \times(\text { concentration in soil })^{-1} \\
\text { (Manskinen et al. 2011) }\end{array}$} \\
\hline \multicolumn{4}{|l|}{ b $\mathrm{NH}_{4} \mathrm{Ac}$-extractable } \\
\hline \multicolumn{4}{|l|}{ c $\mathrm{NH}_{4} \mathrm{Ac}+\mathrm{Na}_{2}$ EDTA-extractable } \\
\hline
\end{tabular}

450-525 ${ }^{\circ} \mathrm{C}$ (Manso et al. 2005; Setien et al. 2009). The latter phase transformation is known to be accompanied by a volume increase of approximately $10 \%$ due to differing crystal structures and respective densities of the two phases (Manso et al. 2005; Setien et al. 2009; Shi 2002; Shi and $\mathrm{Hu}$ 2003). In addition, the hydration of free calcium and magnesium oxide to portlandite and brucite, respectively, are known to be associated with a volume increase of even $100 \%$ (Manso et al. 2005; Setien et al. 2009).

According to Setien et al. (2009), the discussed phase transformations of larnite and hydration of possibly occurring free oxides of calcium and magnesium are the most important morphology-related transformations which can be applied to secondary metallurgical slags. The transformations take place relatively early after slag generation: larnite-related transformations during the temperature decrease of molten slag, and the hydration of free calcium and magnesium oxides during the following hours or days of subsequent exposure to weathering. Potential later changes, such as hydration of calcium aluminates or carbonation of portlandite, are not likely to induce any further changes in the morphology of secondary steelmaking slags (Setien et al. 2009).

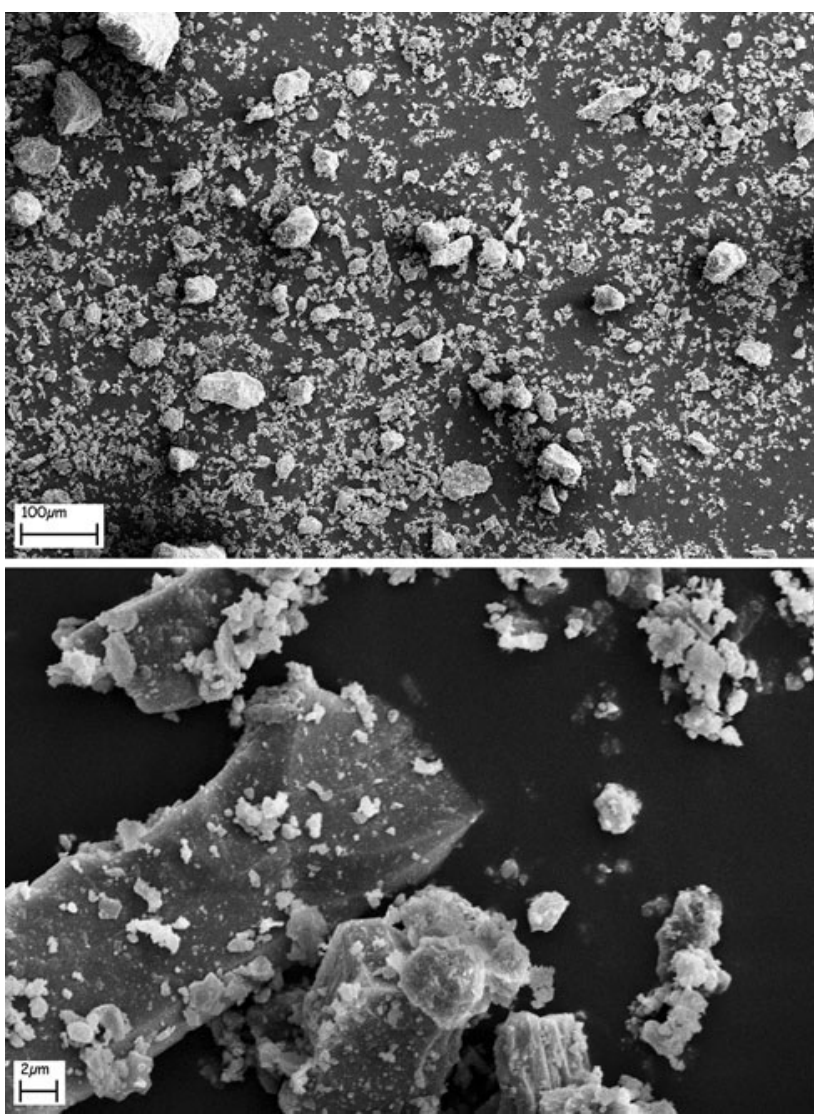

Fig. 2 SEM images of weekly ladle slag samples (12 kV, mag.: top $250 \mathrm{X}$; bottom $6 \mathrm{kX}$ )

Pseudo-total element concentrations of weekly subsamples

The determined pseudo-total concentrations of trace elements and some macroelements ( $\mathrm{Al}, \mathrm{Ca}, \mathrm{Fe}, \mathrm{Mg}, \mathrm{Mn}$, $\mathrm{S}$, and $\mathrm{Ti}$ ) of weekly ladle slag samples and the combined sample are shown in Table 5. Regarding used nomenclature, the term "heavy metal" is disregarded as suggested by the International Union of Pure and Applied Chemistry (UIPAC) (Duffus 2002) and the elements with a determined concentration less than that of $\mathrm{Na}$ in the combined sample (i.e., $390 \mathrm{mg} \mathrm{kg}^{-1}$, d.w., Table 5) are in this study referred to as "trace elements", including metals and metalloids, thus avoiding reference to the biological and toxicological properties of an element. In this investigation, the pseudo-total concentrations were determined to assess how the recognized variation in slag composition (Posch et al. 2002) can affect the content of potentially detrimental trace elements. However, as the objective of the aqua regia digestions is to decompose even some of the silicate structures of the sample matrix and thus depict the worst case environmental scenario where almost the entire 
mineral lattice of the sample matrix becomes labile, no conclusions without the quantification of the labile fraction can be drawn of potential element availability in real environmental conditions.

Based on the data, the pseudo-total concentrations of trace elements were compared to the background concentrations of Finnish fine till (Sorvari 2003) and the literature values of non-contaminated soil (Laine-Ylijoki et al. 2005). In spite of the fact that slag and soil are different media, the naturally occurring levels of trace elements are generally not considered to pose an environmental concern (Proctor et al. 2000). As a result, only $\mathrm{Cr}$ and $\mathrm{V}$ occurred in elevated concentrations (6-week mean values of 198 and $310 \mathrm{mg} \mathrm{kg}^{-1}$, d.w., respectively) and only the mean concentration of $\mathrm{V}$ was attested to exceed the respective background concentration of $3-180 \mathrm{mg} \mathrm{kg}^{-1}$. The residual standard deviation (RSD) values during the 6-week sampling program were 24 and $31 \%$ for $\mathrm{Cr}$ and $\mathrm{V}$, respectively, indicating that fluctuation in desired steel characteristics can have a significant effect on the pseudo-total concentrations of trace elements found in the slag. According to Proctor et al. (2000), hexavalent $\mathrm{Cr}(\mathrm{VI})$ is not formed during steelmaking due to the reducing nature of the process and is likely to be encountered only in electric arc furnace processes where the levels of total $\mathrm{Cr}$ are also
Table 5 Pseudo-total element concentrations of ladle slag weekly and combined samples (aqua regia microwave digestion, $\mathrm{mg} \mathrm{kg}^{-1}$, d.w.) and the Finnish background concentrations of non-contaminated fine till (Sorvari 2003) and literature values for non-contaminated soil (Laine-Ylijoki et al. 2005)

\begin{tabular}{|c|c|c|c|c|c|c|c|c|c|c|c|c|}
\hline \multirow[t]{2}{*}{ Element } & \multicolumn{6}{|c|}{ Sampling week } & \multirow[t]{2}{*}{ Mean } & \multirow[t]{2}{*}{ SD } & \multirow{2}{*}{$\begin{array}{l}\text { RSD } \\
(\%)\end{array}$} & \multirow{2}{*}{$\begin{array}{l}\text { Combined } \\
\text { sample }\end{array}$} & \multirow{2}{*}{$\begin{array}{l}\text { Finnish } \\
\text { background } \\
\text { (non- } \\
\text { contaminated } \\
\text { fine till; } \\
<0.06 \text { ) }\end{array}$} & \multirow{2}{*}{$\begin{array}{l}\text { Non- } \\
\text { contaminated } \\
\text { soil }\end{array}$} \\
\hline & 1 & 2 & 3 & 4 & 5 & 6 & & & & & & \\
\hline
\end{tabular}

\begin{tabular}{|c|c|c|c|c|c|c|c|c|c|c|c|c|}
\hline $\mathrm{Al}$ & 117,000 & 118,000 & 123,000 & 120,000 & 120,000 & 133,000 & 121,833 & 5,845 & 5 & 116,000 & & $10,000-300,000$ \\
\hline As & $<3$ & 4.0 & 5.8 & $<3$ & $<3$ & 3.2 & 4.3 & 1.3 & 31 & 4.1 & $<0.3-20$ & $1-50$ \\
\hline B & 35 & 4.1 & 56 & 37 & 47 & 39 & 36 & 18 & 48 & 39 & & \\
\hline $\mathrm{Ba}$ & 100 & 94 & 71 & 85 & 89 & 78 & 86 & 11 & 12 & 82 & $400-900$ & $100-3,000$ \\
\hline $\mathrm{Be}$ & $<1$ & $<1$ & $<1$ & $<1$ & $<1$ & $<1$ & & & & $<1$ & & \\
\hline $\mathrm{Ca}$ & 280,000 & 265,000 & 286,000 & 268,000 & 279,000 & 286,000 & 277,333 & 8,937 & 3 & 258,000 & & $7,000-500,000$ \\
\hline $\mathrm{Cd}$ & $<0.3$ & $<0.3$ & $<0.3$ & $<0.3$ & $<0.3$ & $<0.3$ & & & & $<0.3$ & & $0.10-0.70$ \\
\hline Co & $<1$ & $<1$ & $<1$ & $<1$ & $<1$ & $<1$ & & & & $<1$ & $<3-30$ & \\
\hline $\mathrm{Cr}$ & 180 & 250 & 140 & 170 & 260 & 190 & 198 & 47 & 24 & 180 & $<30-300$ & $1-1,000$ \\
\hline $\mathrm{Cu}$ & 2.4 & 3.6 & 2.7 & 5.5 & 3.2 & 2.8 & 3.4 & 1.1 & 33 & 3.6 & $10-70$ & $2-100$ \\
\hline $\mathrm{Fe}$ & 9,020 & 10,500 & 6,810 & 14,200 & 10,400 & 7,000 & 9,655 & 2,738 & 28 & 10,100 & & $7,000-550,000$ \\
\hline $\mathrm{Hg}$ & $<0.04$ & $<0.04$ & $<0.04$ & $<0.04$ & $<0.04$ & $<0.04$ & & & & $<0.04$ & & $0.01-0.3$ \\
\hline K & 810 & 900 & 950 & 650 & 1,000 & 930 & 873 & 126 & 14 & 810 & & \\
\hline $\mathrm{Mg}$ & 33,500 & 33,700 & 33,000 & 33,300 & 32,900 & 33,800 & 33,367 & 367 & 1 & 31,400 & & \\
\hline $\mathrm{Mn}$ & 4,120 & 4,190 & 2,900 & 3,960 & 3,910 & 4,260 & 3,890 & 503 & 13 & 3,700 & & $20-3,000$ \\
\hline Mo & 1.8 & 2.0 & 1.5 & 1.6 & 1.9 & 1.4 & 1.7 & 0.2 & 14 & 1.5 & $<0.5->2$ & $0.2-5$ \\
\hline $\mathrm{Na}$ & 500 & 530 & 450 & 620 & 470 & 400 & 495 & 76 & 15 & 390 & & $750-7,500$ \\
\hline $\mathrm{Ni}$ & 5.9 & 7.6 & 4.7 & 7.7 & 4.4 & 4.4 & 5.8 & 1.5 & 27 & 5.0 & $10-100$ & $5-500$ \\
\hline $\mathrm{P}$ & 66 & 120 & 82 & 74 & 120 & 70 & 89 & 25 & 28 & 81 & & \\
\hline $\mathrm{Pb}$ & $<3$ & $<3$ & $<3$ & $<3$ & 3.0 & 4.3 & 3.7 & 0.9 & 25 & 3.3 & $0.1-20$ & $2-200$ \\
\hline$S$ & 1,950 & 1,930 & 2,150 & 2,460 & 2,200 & 1,820 & 2,085 & 233 & 11 & 1,900 & & $20-10,000$ \\
\hline $\mathrm{Sb}$ & $<4$ & $<4$ & $<4$ & $<4$ & $<4$ & $<4$ & & & & $<4$ & $0.1-0.9$ & \\
\hline $\mathrm{Se}$ & 52 & 26 & 26 & 18 & 8.3 & 5.9 & 22.7 & 16.7 & 74 & 22 & & \\
\hline $\mathrm{Sn}$ & $<2$ & $<2$ & $<2$ & $<2$ & $<2$ & $<2$ & & & & $<2$ & & \\
\hline $\mathrm{Ti}$ & 24,200 & 8,720 & 5,100 & 4,560 & 5,070 & 4,460 & 8,685 & 7,765 & 89 & 8,670 & & $1,000-10,000$ \\
\hline V & 300 & 360 & 160 & 330 & 450 & 260 & 310 & 98 & 31 & 300 & $30-180$ & $20-500$ \\
\hline $\mathrm{Zn}$ & 3.2 & 3.9 & 4.4 & 3.1 & 5.7 & 3.8 & 4.0 & 1.0 & 24 & 3,5 & $30-400$ & 10-300 \\
\hline
\end{tabular}

$n=2$ 
higher due to the use of recycled steel. Opposingly, it should be noted that the conditions in a basic oxygen furnace used for the removal of, e.g., $\mathrm{Si}, \mathrm{Ti}$, and $\mathrm{C}$ during converting of crude iron should be regarded as highly oxidizing due to the use of an oxygen blow. However, the prevailing temperatures during converting and the subsequent casting process are generally in the range of $1,500-1,700{ }^{\circ} \mathrm{C}$ and thus likely to be high enough to prevent the stability of $\mathrm{Cr}(\mathrm{VI})$. In this context, the authors are in line with Proctor et al. (2000) stating the possibility for low concentrations of $\mathrm{Cr}(\mathrm{VI})$ due to the cooling of slag under oxidizing conditions in ambient air. The formation of $\mathrm{Cr}(\mathrm{VI})$ in steelmaking was also investigated in our earlier study (Mäkelä et al. 2012) regarding the use of primary basic oxygen furnace slag. In addition to $\mathrm{Cr}$ and $\mathrm{V}, \mathrm{Ba}$ occurred in a 6-week mean concentration of $86 \mathrm{mg} \mathrm{kg}^{-1}$ (d.w.) and a RSD of $12 \%$ suggesting comparatively lower variation than in the case of $\mathrm{Cr}$ and $\mathrm{V}$.

Sequential extraction and mineralogical characterization

Results regarding trace element fractionation according to the revised four-stage BCR extraction procedure and pseudo-total concentration determination with macro elements $\mathrm{Al}, \mathrm{Fe}, \mathrm{Mn}$, and $\mathrm{S}$ are presented in Table 6. In addition, a visual interpretation of element fractionation regarding the combined ladle slag sample is illustrated in Fig. 3. As Table 6 and Fig. 3 depict, the generally emphasized trace elements $\mathrm{As}, \mathrm{Cd}, \mathrm{Cu}, \mathrm{Hg}, \mathrm{Mo}, \mathrm{Ni}, \mathrm{Pb}$, and $\mathrm{Zn}$ were proven not to be of major concern in case of the combined ladle slag sample. As, $\mathrm{Be}, \mathrm{Cd}, \mathrm{Co}, \mathrm{Cu}, \mathrm{Hg}$, $\mathrm{Mo}, \mathrm{Ni}, \mathrm{Pb}, \mathrm{Sb}$, and $\mathrm{Zn}$ attested to minute pseudo-total concentrations ranging from below the limit of quantification $\left(\mathrm{Be}, \mathrm{Cd}, \mathrm{Co}, \mathrm{Hg}\right.$, and $\mathrm{Sb}$ ) to $5.0 \mathrm{mg} \mathrm{kg}^{-1}$, d.w. $(\mathrm{Pb})$ with increased extractability $(43-109 \%$ of the respective pseudo-total concentration, see Fig. 3) associated with step 4 of the sequential extraction procedure. Only $\mathrm{Ni}$ was extracted during step 2 of the sequential extraction procedure, with a minor recovery of $1.1 \mathrm{mg} \mathrm{kg}^{-1}$ (d.w.). In addition, $\mathrm{Cu}, \mathrm{Ni}$, and $\mathrm{Zn}$ were also recovered during step 3 of the extraction procedure in respective concentrations of $0.82,0.79$, and $2 \mathrm{mg} \mathrm{kg}^{-1}$ (d.w.). Trace elements $\mathrm{Be}, \mathrm{Cd}, \mathrm{Co}, \mathrm{Hg}$, and $\mathrm{Sb}$ which were found below the limit of quantification during steps 1-4 of the sequential extraction procedure were thus not included in Fig. 3.

Only trace elements $\mathrm{Ba}, \mathrm{Cr}, \mathrm{Se}$, and $\mathrm{V}$ were recovered in noticeable concentrations during the sequential extraction procedure. In the case of $\mathrm{Se}$, the low pseudo-total concentration of $22 \mathrm{mg} \mathrm{kg}^{-1}$ (d.w.) and a cumulative recovery of $5.4 \mathrm{mg} \mathrm{kg}^{-1}$ (d.w.) during steps 1 and 2 support the notion that the availability of Se should not pose an environmental risk during ladle slag handling, utilization, or landfilling procedures. In general, $\mathrm{Se}$ occurs in four important oxidation states: -II, elemental, IV, and VI, which in soils are mainly governed by adsorption, precipitation, and transformation. In soils, elemental Se often occurs with $\mathrm{S}$ compounds such as selenium sulfide $\left(\mathrm{Se}_{2} \mathrm{~S}_{2}\right)$ and can be easily oxidized to selenite $\left(\mathrm{SeO}_{3}{ }^{2-}\right)$ and selenate $\left(\mathrm{SeO}_{4}{ }^{2-}\right)$ of which selenate is fairly soluble and thus potentially available in natural conditions (Adriano 2001; Keskinen et al. 2009). In Finland, agricultural fertilizers have been spiked with sodium selenate since 1984 due to locally Se-poor bedrock and soils, corroborated by prevailing acidic and reducing soil conditions favoring selenite sorption and precipitation in the elemental form (Keskinen et al. 2009). During the sequential extraction procedure, most of the extracted Se (i.e., $11 \mathrm{mg} \mathrm{kg}^{-1}$, d.w.) was recovered during step 3 indicating the potential oxidation of sulfides (see Table 1). As illustrated in Fig. 4, the occurrence of sulfides in the base sample and thus respective decomposition during sequential extraction was not detected by means of XRD used to analyze the residues of parallel sequential extractions. It must be noted though that the detection limit of an X-ray diffractometer is generally in the range of $1-2 \% \mathrm{w} / \mathrm{w}$ making the detection of potential sample sulfides difficult even with a pseudo-total $\mathrm{S}$ concentration of $1,900 \mathrm{mg} \mathrm{kg}^{-1}$ (d.w., see Table 6). In soils and sediments, Se occurrence with gibbsite $\left[\mathrm{Al}(\mathrm{OH})_{3}\right]$ has been reported (Adriano 2001), which in our case was detected after step 3 (see step 3 res. in Fig. 4). The RSD value of Se during the 6-week sampling program was $74 \%$ indicating significant variation in the Se contents of ladle slag.

In the case of $\mathrm{Cr}$, environmental concern is generally placed on the potential existence of $\mathrm{Cr}(\mathrm{VI})$, or possible oxidation of $\mathrm{Cr}(\mathrm{III})$ to $\mathrm{Cr}(\mathrm{VI})$, which mainly stipulate Cr toxicity (Fandeur et al. 2009). In addition to the discussion in "Pseudo-total element concentrations of weekly subsamples", a routine analysis combining water extraction according to the two-stage batch test SFS-EN 12457-3 (L/S 10) and subsequent supernatant analysis by (1,5-)diphenylcarbatzide addition followed by absorbance quantification with a PerkinElmer (PerkinElmer, Norwalk, USA) Lambda 25 spectrophotometer was performed on two combined three-week ladle slag samples representative of the equivalent sampling period. The resulting labile $\mathrm{Cr}(\mathrm{VI})$ concentration values were equivalent for both samples: $0.1 \mathrm{mg} \mathrm{kg}^{-1}$ (d.w.). Considering the solubility of $\mathrm{Cr}(\mathrm{III})$ and $\mathrm{Cr}(\mathrm{VI})$ of which the former is relatively insoluble in water and latter highly soluble (Stam et al. 2011) at least an indication of the existence of $\mathrm{Cr}(\mathrm{VI})$ should have been detected if oxidation of $\mathrm{Cr}(\mathrm{III})$ would have occurred upon cooling of the slag phase. 
Table 6 Fractionation of trace elements and $\mathrm{Al}, \mathrm{Fe}, \mathrm{Mn}$ and $\mathrm{S}$ in $\mathrm{mg} \mathrm{kg}^{-1}$ (d.w.) in the combined ladle slag sample based on the revised fourstage BCR extraction procedure with respective pseudo-total concentrations and calculated fraction recoveries

\begin{tabular}{|c|c|c|c|c|c|c|}
\hline Element & Step 1 & Step 2 & Step 3 & Step 4 & Pseudo-total & Recovery (\%) \\
\hline $\mathrm{Al}$ & 2,100 & 31.2 & 74,000 & 45,000 & 116,000 & 104.4 \\
\hline As & $<0.6$ & $<0.6$ & $<0.75$ & 4.0 & 4.1 & 97.6 \\
\hline $\mathrm{Ba}$ & 12.3 & 44.0 & 19.4 & 7.9 & 82 & 102.0 \\
\hline $\mathrm{Be}$ & $<0.2$ & $<0.2$ & $<0.2$ & $<0.25$ & $<1$ & \\
\hline $\mathrm{Cd}$ & $<0.08$ & $<0.08$ & $<0.1$ & $<0.2$ & $<0.3$ & \\
\hline Co & $<0.2$ & $<0.2$ & $<0.25$ & $<0.5$ & $<1$ & \\
\hline $\mathrm{Cr}$ & $<0.4$ & 2.1 & 52.7 & 135 & 180 & 105.4 \\
\hline $\mathrm{Cu}$ & $<0.4$ & $<0.4$ & 0.82 & 3.1 & 3.6 & 108.9 \\
\hline $\mathrm{Fe}$ & $<1$ & 2,440 & 2,360 & 6,150 & 10,100 & 108.4 \\
\hline $\mathrm{Hg}$ & $<0.02$ & $<0.02$ & $<0.025$ & $<0.05$ & $<0.04$ & \\
\hline $\mathrm{Mn}$ & $<0.4$ & 2,550 & 1,000 & 518 & 3,700 & 109.9 \\
\hline Mo & $<0.2$ & $<0.2$ & $<0.25$ & 1.6 & 1.5 & 106.7 \\
\hline $\mathrm{Ni}$ & $<0.2$ & 1.1 & 0.79 & 3.1 & 5.0 & 99.8 \\
\hline $\mathrm{Pb}$ & $<0.6$ & $<0.6$ & $<0.75$ & 3.6 & 3.3 & 109.1 \\
\hline $\mathrm{S}$ & 6.4 & 880 & 800 & 300 & 1,900 & 104.5 \\
\hline $\mathrm{Sb}$ & $<0.6$ & $<0.6$ & $<0.75$ & $<2$ & $<4$ & \\
\hline $\mathrm{Se}$ & 3.1 & 2.3 & 11 & 3.0 & 22 & 88.2 \\
\hline V & $<0.4$ & 123 & 4.7 & 178 & 300 & 101.9 \\
\hline $\mathrm{Zn}$ & $<0.4$ & $<0.4$ & 2 & 1.5 & 3.5 & 100.0 \\
\hline
\end{tabular}

$n=2$
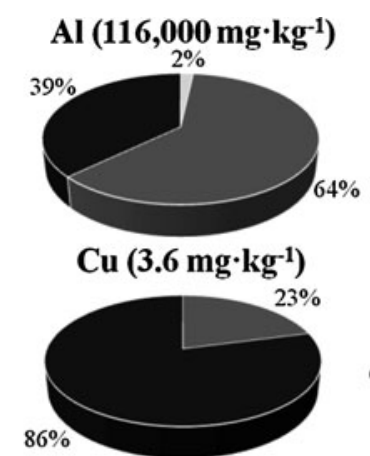

$\mathrm{Ni}\left(5.0 \mathrm{mg} \cdot \mathrm{kg}^{-1}\right)$

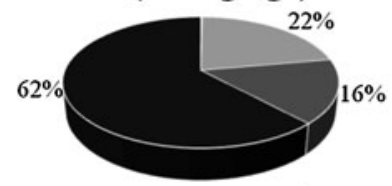

V (300 $\left.\mathrm{mg} \cdot \mathrm{kg}^{-1}\right)$

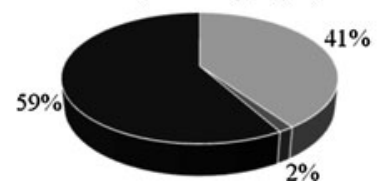

$41 \%$

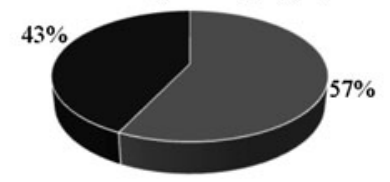

As (4.1 $\left.\mathrm{mg} \cdot \mathrm{kg}^{-1}\right)$

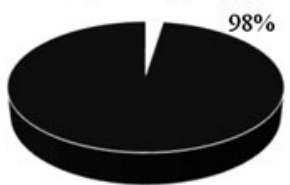

Fe $\left(10,100 \mathrm{mg} \cdot \mathrm{kg}^{-1}\right)$

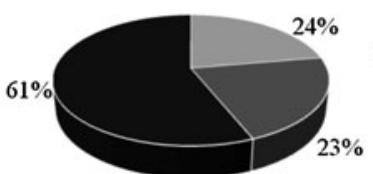

$\mathrm{Pb}\left(3.3 \mathrm{mg} \cdot \mathrm{kg}^{-1}\right)$

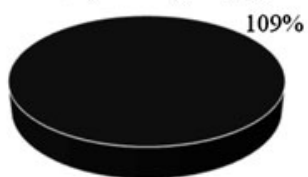

$\mathrm{Zn}\left(3.5 \mathrm{mg} \cdot \mathrm{kg}^{-1}\right)$

Fig. 3 Element fractionation of the combined ladle slag sample based on the revised four-stage sequential BCR extraction procedure with respective pseudo-total element concentration determinations (in
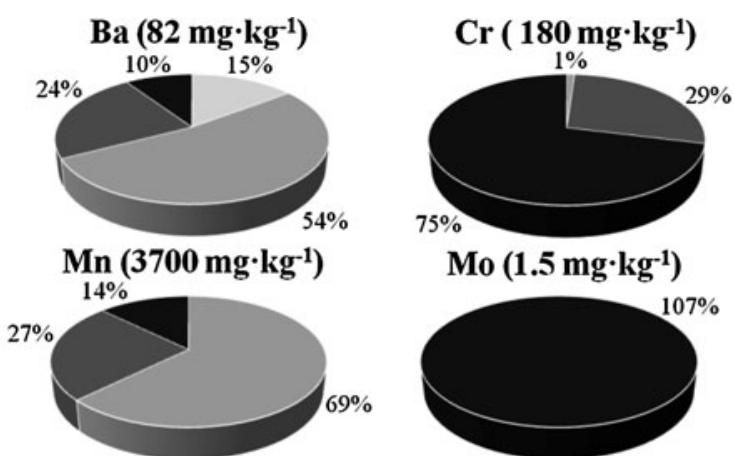

Mo $\left(1.5 \mathrm{mg} \cdot \mathrm{kg}^{-1}\right)$
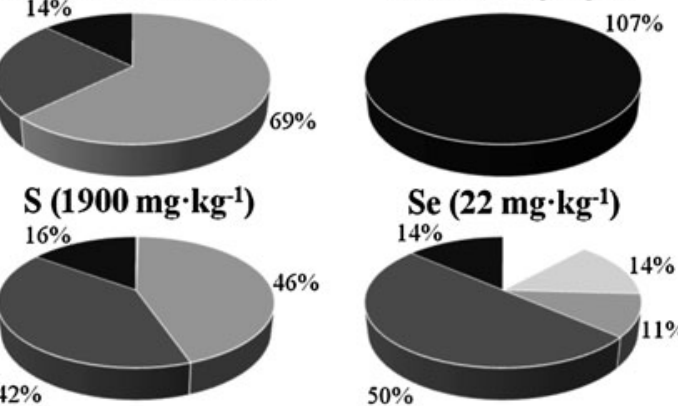

Se (22 mg $\left.\mathrm{kg}^{-1}\right)$

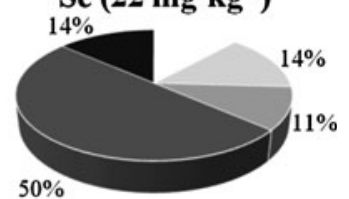

Step 1

$\because$ Step 2

- Step 3

- Step 4 parentheses, d.w.). Step recovery (\%) calculation based on determined pseudo-total concentrations 
Fig. 4 X-ray diffractograms of the combined ladle slag sample (base sample) and respective step residues (step 1-4 res.) from the revised four-stage $\mathrm{BCR}$ extraction procedure
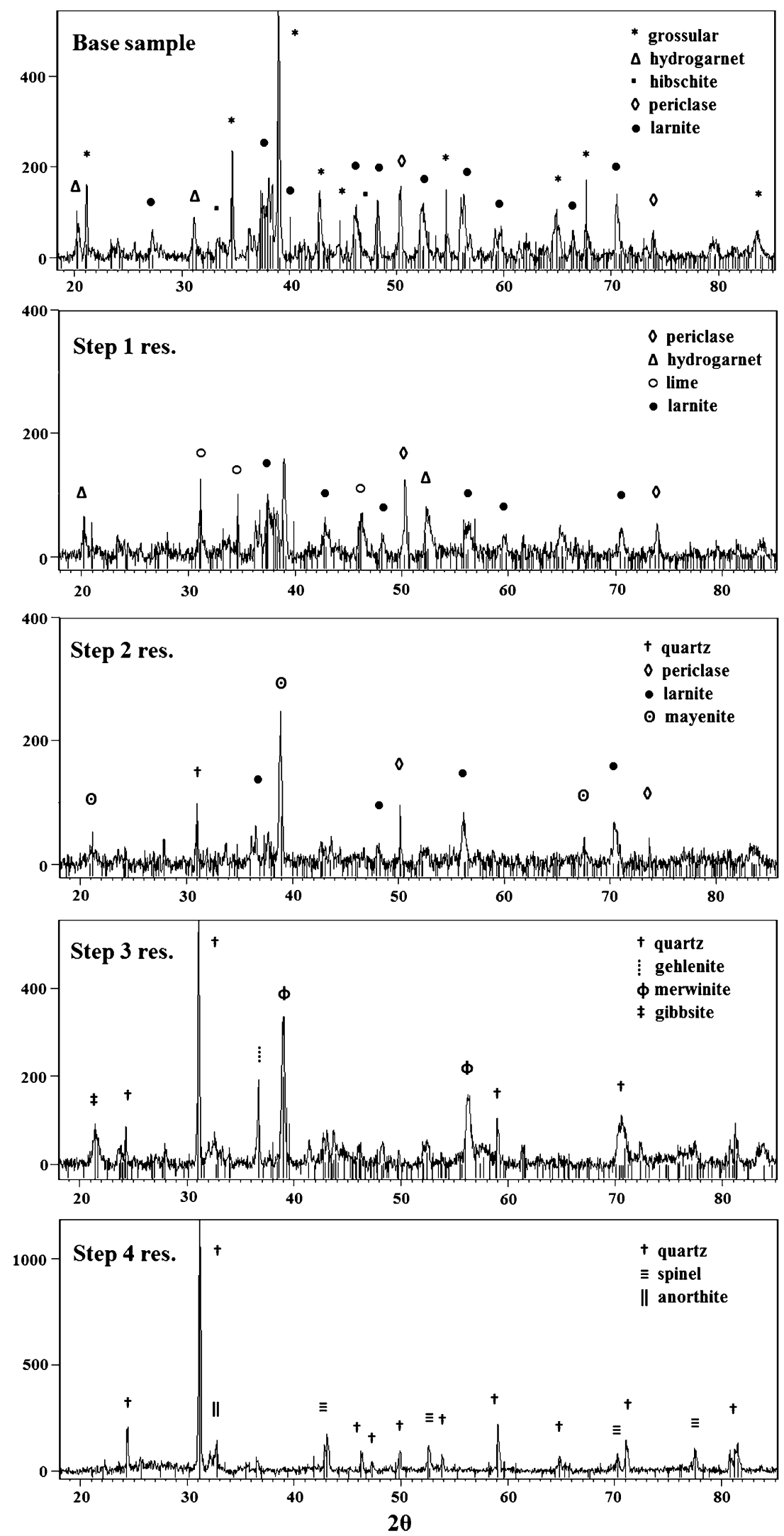
According to the sequential extraction procedure, $\mathrm{Cr}$ was mostly recovered during step 4 (135 $\mathrm{mg} \mathrm{kg}^{-1}$, d.w.) indicating dominant occurrence in the residual fraction, as only 2.1 and $52.7 \mathrm{mg} \mathrm{kg}^{-1}$ (d.w.) were recovered during steps 2 and 3, respectively. Again, any indication regarding the occurrence of sulfide-containing minerals in the base sample or residues of successive extraction steps of the procedure was not attained by XRD which only supported the existence of quartz $\left[\mathrm{SiO}_{2}\right]$, gehlenite $\left[\mathrm{Ca}_{2} \mathrm{Al}_{2} \mathrm{SiO}_{7}\right]$, merwinite $\left[\mathrm{Ca}_{3} \mathrm{Mg}\left(\mathrm{SiO}_{4}\right)_{2}\right]$, and gibbsite after step 3 and quartz, spinel group structures $\left[\mathrm{MgAl}_{2} \mathrm{O}_{4}\right]$, and anorthite $\left[\mathrm{Al}_{2} \mathrm{Ca}\left(\mathrm{SiO}_{4}\right)_{2}\right]$ after step 4 (see Fig. 4). The detection of $\mathrm{Mg}$ in the mineralogy of the residues from steps 3 and 4, as opposed to the possible base sample periclase $[\mathrm{MgO}]$ detected in step 1 and 2 res., suggests non-selectivity of the procedure towards periclase and redistribution of $\mathrm{Mg}$ during extraction with hydrogen peroxide and ammonium acetate during step 3 . According to Young et al. (2005), redistribution during sequential extraction from soil samples could arise from increases in element ion activity in solution, changes in $\mathrm{pH}$, or the exposure of new adsorption surfaces causing readsorption on remaining adsorbents. It must be noted that alternative approaches for the use of XRD in support of sequential extraction procedures are limited as maintaining comparability between different laboratories requires strict adherence to the procedures (Bacon and Davidson 2008; Pueyo et al. 2001). More research is needed regarding the use of intermediate, non-destructive analytical techniques in tandem with sequential extraction procedures, which would, however, increase the frequently criticized tediousness of the procedures (Jamali et al. 2009; Nemati et al. 2010).

Trace element $\mathrm{Ba}$ was recovered during all steps of the sequential extraction procedure with recovered concentrations of 12.3 and $44.0 \mathrm{mg} \mathrm{kg}^{-1}$ (d.w.) during the most labile steps 1 and 2, respectively. The use of acetic acid at $\mathrm{pH} 2$ during step 1 has been reported to describe approximately the sum of water soluble, exchangeable and carbonate-bound phases and thus the most active and available fraction of an element (Li et al. 2010). Although the buffering capacity of the ladle slag sample is likely to maintain neutral to alkaline conditions in the proximity of slag particles, acetic acid is a realistic choice to simulate a plausible worst case scenario if the waste material is co-disposed with, e.g., municipal solid waste (Svensson et al. 2005). Hydroxylamine hydrochloride in a nitric acid medium during step 2 is used to recover easily or moderately reducible phases made available through changes in prevailing redox conditions and thus simulates anoxic conditions likely to occur in a natural medium (Manskinen et al. 2011; Rao et al. 2008). Under disposal conditions, abiotic transformations leading to the formation of reducing gases $\left(\mathrm{H}_{2}\right)$ could result in redox reactions in disposed slag (Sabbas et al. 2003). In nature, $\mathrm{Ba}$ occurs mainly as barite $\left[\mathrm{BaSO}_{4}\right]$ and withewrite $\left[\mathrm{BaCO}_{3}\right]$ and concentrations of $200 \mathrm{mg} \mathrm{kg}^{-1}$ upon digestion have been found moderately toxic (Nogueira et al. 2010). Although Nogueira et al. (2010) claim more local and international attention for $\mathrm{Ba}$ accumulation in soil and water bodies, a potentially labile concentration of $44.0 \mathrm{mg} \mathrm{kg}^{-1}$ (d.w.) during step 2 and a rather low pseudo-total concentration of $82 \mathrm{mg} \mathrm{kg}^{-1}$ (d.w.) suggest that $\mathrm{Ba}$ is not an element of major concern. In addition, as illustrated in Table 5 and discussed in "Pseudo-total element concentrations of weekly subsamples", a RSD value of $12 \%$ during the 6-week sampling program indicates that $\mathrm{Ba}$ contents in ladle slag are not susceptible to major variation. According to the data acquired by XRD, only the existence of quartz, periclase, larnite $\left[\mathrm{Ca}_{2} \mathrm{SiO}_{4}\right]$, and mayenite $\left[\mathrm{Ca}_{12} \mathrm{Al}_{14} \mathrm{O}_{33}\right]$ was detected after step 2, as opposed to periclase, hydrogarnet $\left[\mathrm{Al}_{2} \mathrm{O}_{3}(\mathrm{CaO})_{3}\left(\mathrm{H}_{2} \mathrm{O}\right)_{6}\right]$, lime $[\mathrm{CaO}]$, and larnite detected after step 1. The potential dissolution of larnite during step 3 is surprising, as recovery of silicates should not be anticipated until the final extraction step (i.e., step 4) of the procedure. According to our data, larnite and quartz were detected after steps 1-2 and 2-4, respectively, in addition to the gehlenite and merwinite structures detected in step 3 res. shown in Fig. 4. Especially in the case of slag materials, our observations confirm the purely operational nature of sequential extraction procedures, which should thus not be referred to as target phase specific. The lack of phase specificity has also been confirmed by other authors combining the use of X-raybased analytical methods with the BCR procedure (Ryan et al. 2008; Sulkowski and Hirner 2006).

In addition to $\mathrm{Se}, \mathrm{Cr}$, and $\mathrm{Ba}$, only trace element $\mathrm{V}$ occurred with a considerable pseudo-total concentration of $300 \mathrm{mg} \mathrm{kg}^{-1}$ (d.w.) in the combined ladle slag sample. Respectively, $123 \mathrm{mg} \mathrm{kg}^{-1}$ (d.w.) of $\mathrm{V}$ amounting to $41 \%$ of the respective pseudo-total concentration was recovered during step 2 of the extraction procedure. Potential correlation with or substitution for Fe (oxyhydroxides) has been suggested by, e.g., Adriano (2001) for V in soils. However, it must be noted that $\mathrm{Fe}$ was also recovered during step 3 (2,360 $\mathrm{mg} \mathrm{kg}^{-1}$, d.w.) in which $\mathrm{V}$ showed very low availability, which could be an indication of the occurrence of both ferric and ferrous $\mathrm{Fe}$ in the sample. According to Ryan et al. (2008), the presence of ferric and ferrous Fe in, e.g., silicate clays indicates respective reduction and oxidation potential during subsequent extractions by hydroxylamine hydrochloride and hydrogen peroxide with ammonium acetate in steps 2 and 3 . An average concentration of $\mathrm{V}$ in soil is in the range of $10-220 \mathrm{mg} \mathrm{kg}^{-1}$ (Połedniok and Buhl 2003) which is in agreement with the Finnish background 


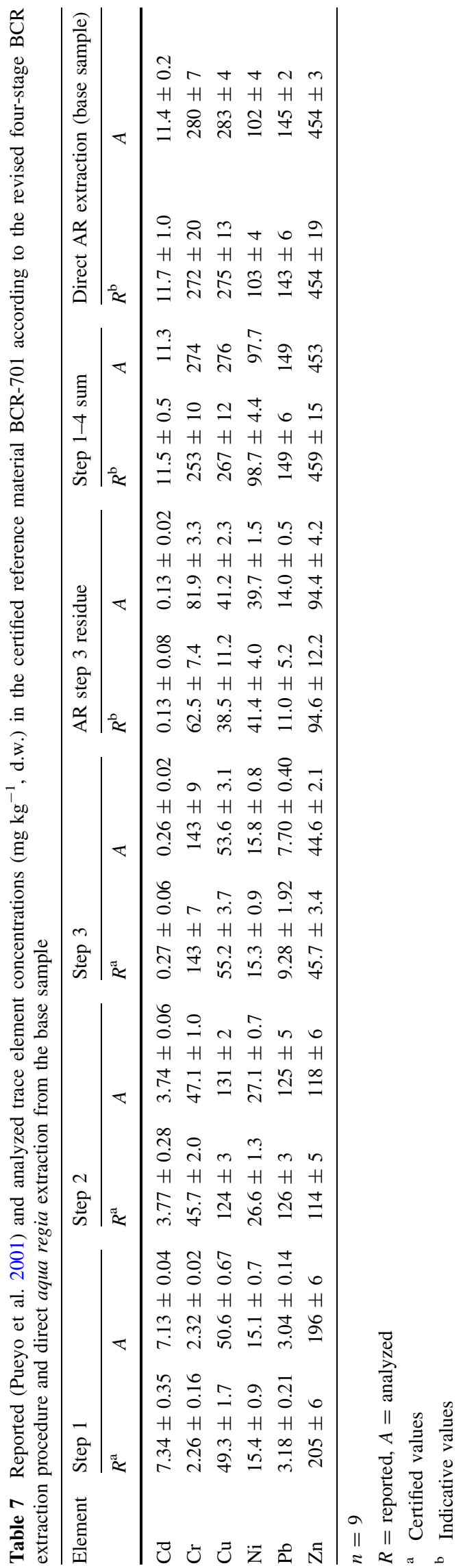

value of $30-180 \mathrm{mg} \mathrm{kg}^{-1}$ (d.w.) provided in Table 5. In addition to $\mathrm{V}$ availability during step 2, most of the pseudototal concentration of $\mathrm{V}\left(59 \%, 178 \mathrm{mg} \mathrm{kg}^{-1}\right.$, d.w.) was attested to occur in the residual fraction extracted during step 4. However, a $\mathrm{V}$ recovery of $123 \mathrm{mg} \mathrm{kg}^{-1}$ (d.w.) during step 2 can be considered as an indication of potential phytoavailability in natural conditions.

Reproducibility and analytical performance of the sequential extraction procedure

For the validation of the adopted approach, the sum of recoveries during steps $1-4$ of the sequential extraction procedure were compared with the respective pseudo-total concentration values determined by direct aqua regia extraction from the combined sample (Table 6). In addition, the analyzed step values $(n=9)$ of the CRM BCR701 attained from the Institute for Reference Materials and Measurements (IRMM, Geel, Belgium) were compared with certified and indicative values for $\mathrm{Cd}, \mathrm{Cr}, \mathrm{Cu}, \mathrm{Ni}, \mathrm{Pb}$, and $\mathrm{Zn}$ reported by Pueyo et al. (2001) as illustrated in Table 7. According to Sutherland (2010, pp. 11), a majority of studies reporting the implementation of the BCR procedure fail to include CRM analysis as a part of quality control. Sutherland (2010) also reported certified and indicative values for BCR-701, however excluding the sum of steps 1-4 and with minor deviations in the individual values compared to Pueyo et al. (2001). Hence, analyzed CRM BCR-701 values were compared to those reported by Pueyo et al. (2001).

According to the data, the recovery of individual elements during the sequential extraction procedure (steps 1-4) ranged from 88.2 to $109.9 \%$ (Se and $\mathrm{Pb}$, respectively), with increasing uncertainty related to a minute pseudo-total concentration or macro element analysis (note that the minor deviations compared to the sum of recoveries calculated from Fig. 3 are due to the round off of individual values). The attained recoveries are reasonable as the BCR procedure was not originally designed for slag materials with, e.g., characteristic elevated concentrations of $\mathrm{Al}, \mathrm{Fe}$, and $\mathrm{Mn}$. In addition, $\mathrm{Cd}, \mathrm{Cu}, \mathrm{Ni}, \mathrm{Pb}$, and $\mathrm{Zn}$ incorporated in CRM analysis were found only in minute concentrations in the combined ladle slag sample (see Table 6) confirming the different original purpose of the method. Especially with slag materials with characteristic high buffering capacities, the $\mathrm{pH}$ values of individual extraction solutions are likely to rise excessively high to favor the adsorption of normally monitored contaminants instead of desorption (Sulkowski and Hirner 2006).

The analyzed values of CRM BCR-701 were generally within the uncertainty limits reported by Pueyo et al. (2001) with only four exceptions, i.e., Zn recovery during 
step $1, \mathrm{Cu}$ recovery during step $2, \mathrm{Cr}$ recovery during step 4 , and the step 1-4 sum of Cr. In addition, the standard deviations of the presented experimental results were generally lower than the certified or indicative inter-laboratory values. As a result, it can be stated that sufficient analytical quality was maintained during the entire sequential extraction procedure. Based on the authors' experience, sequential extraction procedures can be useful tools in providing information for environmental risk assessment of a wide range of materials. In Finland, policies for landfilling and utilization activities are largely based on the use of batch leaching tests and pseudo-total concentration determinations of potentially detrimental elements. Although useful in certain context, these analytical procedures fail to describe the effects of potential changes in the surrounding media on the mobility of contaminants as the batch leaching tests only provide lability data under circumneutral conditions. However, a major uncertainty regarding the use of the BCR procedure is associated with the interpretation of results, such as assuming target phase specificity, which was clearly not supported by our results.

\section{Conclusion}

Based on the comprehensive characterization of the weekly and combined ladle slag samples, the slag material possessed a NV of $32.4 \%$ (Ca equivalents, d.w.) and an angular-like morphology, in which the temperature decrease induced phase transformations have a significant effect on the distinguishable size fractions of approximately $1-10$ and $100 \mu \mathrm{m}$ in diameter. According to the pseudo-total element concentration determinations, only $\mathrm{Cr}$ and $\mathrm{V}$ occurred in elevated concentrations with respective 6-week mean values of 198 and $310 \mathrm{mg} \mathrm{kg}^{-1}$ (d.w.). The RSD values of the aforementioned elements ( 24 and $31 \%$, respectively) indicated that significant variation in the concentration of trace elements can occur due to fluctuation in process conditions and/or slag characteristics. In terms of trace element availability, the revised four-stage BCR extraction procedure performed on a representative combined ladle slag sample provided useful data for risk assessment in support of environmental policy. According to the results, only trace elements $\mathrm{Ba}, \mathrm{Cr}$, and $\mathrm{V}$ were attested as potentially available in noticeable concentrations. $\mathrm{Cr}$ availability was mainly associated with steps 3 $\left(\mathrm{H}_{2} \mathrm{O}_{2}+\mathrm{CH}_{3} \mathrm{COONH}_{4}\right)$ and 4 (aqua regia digestion) with respective concentrations of 52.7 and $135 \mathrm{mg} \mathrm{kg}^{-1}$ (d.w.). $\mathrm{Ba}$ availability occurred also during the more labile steps of extraction procedure with recoveries of 12.3 and
$44.0 \mathrm{mg} \mathrm{kg}^{-1}$ (d.w.) during steps $1\left(\mathrm{CH}_{3} \mathrm{COOH}\right)$ and 2 $\left(\mathrm{NH}_{2} \mathrm{OH} \cdot \mathrm{HCl}\right)$, respectively. In the case of $\mathrm{V}$, a recovery of $123 \mathrm{mg} \mathrm{kg}^{-1}$, d.w., during step 2 amounting to $41 \%$ of the respective pseudo-total concentration (i.e., $300 \mathrm{mg} \mathrm{kg}^{-1}$, d.w.) indicated potential phytoavailability in natural conditions through, e.g., changes in prevailing redox conditions. Although the mineralogical characterization of parallel sequential extraction residues indicated nonselectivity of the procedure coupled with potential redistribution phenomena during step 3, the analytical approach was validated by the analysis of a certified reference material and the calculation of extraction recoveries.

Acknowledgments The authors would like to thank the staff at Suomen Ympäristöpalvelu Oy, for kindly performing the chemical analyses. Additionally, the contributions of D.Sc. Erkki Heikinheimo from the Department of Materials Science and Engineering (Aalto University, School of Chemical Technology) in SEM imaging and the two anonymous referees for their valuable comments for enhancing the manuscript are deeply appreciated.

\section{References}

Adriano DC (2001) Trace elements in terrestrial environments, 2nd edn. Springer-Verlag, New York

Anju A, Banerjee DK (2010) Comparison of two sequential extraction procedures for heavy metal partitioning in mine tailings. Chemosphere 78(11):1393-1402

Bacon JR, Davidson CM (2008) Is there a future for sequential chemical extraction? Analyst 133(1):25-46

Cottrell A (1975) Iron and steel making. In: Cottrell A (ed) An introduction to metallurgy. Edward Arnold Ltd., London, pp 122-142

Dahlin CL, Williamson CA, Collins WK, Dahlin DC (2002) Sequential extraction versus comprehensive characterization of heavy metal species in Brownfield soils. Environ Forensics 3(2):191-201

Duffus JF (2002) "Heavy metals"-a meaningless term? Pure Appl Chem 74(5):793-807

Fandeur D, Juillot F, Morin G, Olivi L, Cognini A, Webb SM, Ambrosi JP, Fritsch E, Guyot F, Brown GE Jr (2009) XANES evidence for oxidation of $\mathrm{Cr}(\mathrm{III})$ to $\mathrm{Cr}(\mathrm{VI})$ by Mn-oxides in a lateritic regolith developed on serpentinized ultramafic rocks of New Caledonia. Environ Sci Technol 43(19):7384-7390

Filgueiras AV, Lavilla I, Bendicho C (2002) Chemical sequential extraction for metal partitioning in environmental solid samples. J Environ Monit 4(6):823-857

Fuentes A, Lloréns M, Sáez J, Soler A, Aguilar MI, Ortuño JF, Meseguer VF (2004) Simple and sequential extractions of heavy metals from different sewage sludges. Chemosphere 54(8): 1039-1047

Gleyzes C, Tellier S, Astruc M (2002) Fractionation studies of trace elements in contaminated soils and sediments: a review of sequential extraction procedures. Trends Anal Chem 21(6-7): 451-467

Heiri O, Lotter AF, Lemcke G (2001) Loss on ignition as a method for estimating organic and carbonate content in sediments: reproducibility and comparability of results. J Paleolimnol 25(1):101-110 
Jamali MK, Kazi TG, Arain MB, Afridi HI, Jalbani N, Kandhro GA, Shah AQ, Baig JA (2009) Speciation of heavy metals in untreated sewage sludge by using microwave assisted sequential extraction procedure. J Hazard Mater 163(2-3):1157-1164

Kazi TG, Jamali MK, Kazi GH, Arain MB, Afridi HI, Siddiqui A (2005) Evaluating the mobility of toxic metals in untreated industrial wastewater sludge using a BCR sequential extraction procedure and a leaching test. Anal Bioanal Chem 383(2): 297-304

Keskinen R, Ekholm P, Yli-Halla M, Hartikainen H (2009) Efficiency of different methods in extracting selenium from agricultural soils in Finland. Geoderma 153(1-2):87-93

Laine-Ylijoki J, Rouch UM, Vahanne P, Wahlström M, Vestola E, Salonen S, Havukainen J (2005) Current international status of MSW ashes and slags (in Finnish, abstract in English). VTT research notes. Available at: http://www.vtt.fi/inf/pdf/tiedotteet/ 2005/T2291.pdf. Accessed 21 Jun 2011

Li J, Lu Y, Shim H, Deng X, Lian J, Lia Z, Li J (2010) Use of the $\mathrm{BCR}$ sequential extraction procedure for the study of metal availability to plants. J Environ Monit 12(2):466-471

Mäkelä M, Watkins G, Pöykiö R, Nurmesniemi H, Dahl O (2012) Utilization steel, pulp and paper industry solid residues in forest soil amendment: relevant physicochemical properties and heavy metal availability. J Hazard Mater 207-208:21-27

Manskinen K, Nurmesniemi H, Pöykiö R (2011) Total and extractable non-process elements in green liquor dregs from the chemical recovery circuit of a semi-chemical pulp mill. Chem Eng J 166(3):954-961

Manso JM, Losañez M, Polanco JA, Gonzalez JJ (2005) Ladle furnace slag in construction. J Mater Civ Eng 17(5):513-518

Marguí E, Salvadó V, Queralt I, Hidalgo M (2004) Comparison of three-stage sequential extraction and toxicity characteristic leaching tests to evaluate metal mobility. Anal Chim Acta 524(1-2):151-159

Martínez-Fernández M, Barciela-Alonso MC, Moreda-Piñeiro A, Bermejo-Barrera P (2011) Matrix solid phase dispersion-assisted BCR sequential extraction method for metal partitioning in surface estuarine sediments. Talanta 83(3):840-849

Nemati K, Bakar NKA, Abas Mhd A, Sobhanzadeh E (2010) Speciation of heavy metals by modified BCR sequential extraction procedure in different depths of sediments from Sungai Buloh, Selangor, Malaysia. J Hazard Mater 192(1): 402-410

Nogueira TAR, deMelo WJ, Fonseca IM, Marquez MO, He Z (2010) Barium uptake by maize plants as affected by sewage sludge in a long-term field study. J Hazard Mater 181(1-3): $1148-1157$

Nurmesniemi H, Pöykiö R, Kuokkanen T, Rämö J (2008) Chemical sequential extraction of heavy metals and sulphur in bottom ash and in fly ash from a pulp and paper mill complex. Waste Manag Res 26(4):389-399

Połedniok J, Buhl F (2003) Speciation of vanadium in soil. Talanta 59(1):1-8

Posch W, Presslinger H, Hiebler H (2002) Mineralogical evaluation of ladle slads at voestalpine Stahl GmbH. Ironmaking Steelmaking 29(4):308-312

Pöykiö R, Rönkkömäki H, Nurmesniemi H, Perämäki P, Kopov K, Välimäki I, Tuomi T (2009) Chemical and physical properties of cyclone fly ash from the grate-fired boiler incinerating forest residues at a small municipal district heating plant (6 MW). J Hazard Mater 162(2-3):1059-1064

Proctor DM, Fehling KA, Shay EC, Wittenborn JL, Green JJ, Avent C, Bigham RD, Connolly M, Lee B, Shepker TO, Zak MA
(2000) Physical and chemical characteristics of blast furnace, basic oxygen furnace, and electric arc furnace steel industry slags. Environ Sci Technol 34(8):1576-1582

Pueyo M, Rauret G, Lück D, Yli-Halla M, Muntau H, Quevauviller Ph, López-Sánchez JF (2001) Certification of the extractable contents of $\mathrm{Cd}, \mathrm{Cr}, \mathrm{Cu}, \mathrm{Ni}, \mathrm{Pb}$ and $\mathrm{Zn}$ in a freshwater sediment following a collaboratively tested and optimized three-step sequential extraction procedure. J Environ Monit 3(2):243-250

Pueyo M, Mateu J, Rigol A, Vidal M, López-Sánchez JF, Rauret G (2008) Use of the modified BCR three-step sequential extraction procedure for the study of trace element dynamics in contaminated soils. Environ Pollut 152(2):330-341

Rao CRM, Sahuquillo A, Lopez Sanchez JF (2008) A review of the different methods applied in environmental geochemistry for single and sequential extraction of trace elements in soils and related materials. Water Air Soil Pollut 189(1-4):291333

Rauret G, López-Sánchez JF, Sahuquillo A, Rubio R, Davidson C, Ure A, Quevauviller Ph (1999) Improvement of the BCR three step sequential extraction procedure prior to the certification of new sediment and soil reference materials. J Environ Monit 1(1):57-61

Ryan PC, Hillier S, Wall AJ (2008) Stepwise effects of the BCR sequential chemical extraction procedure on dissolution and metal release from common ferromagnesian clay minerals: a combined solution chemistry and X-ray powder diffraction study. Sci Total Environ 407(1):603-614

Sabbas T, Polettini A, Pomi R, Astrup T, Hjelmar O, Mostbauer P, Cappai G, Magel G, Salhofer S, Speiser C, Heuss-Assbichler S, Klein R, Lechner P (2003) Management of municipal solid waste incineration residues. Waste Manag (Oxf) 23(1):61-88

Setien J, Hernández D, González JJ (2009) Characterization of ladle furnace basic slag for use as a construction material. Constr Build Mater 23(5):1788-1794

Shi C (2002) Characteristics and cementitious properties of ladle slag fines from steel production. Cem Concr Res 32(3):459-462

Shi C, Hu S (2003) Cementitious properties of ladle slag fines under autoclave curing conditions. Cem Concr Res 33(11): $1851-1856$

Smeda A, Zyrnicki W (2002) Application of sequential extraction and the ICP-AES method for study of the partitioning of metals in fly ashes. Microchem J 72(1):9-16

Sorvari J (2003) By-products in earth construction: environmental assessments. J Environ Eng 129(10):899-909

Stam AF, Meij R, te Winkel H, van Eijk RJ, Huggins FE, Brem G (2011) Chromium speciation in coal and biomass co-combustion products. Environ Sci Technol 45(6):2450-2456

Sulkowski M, Hirner AV (2006) Element fractionation by sequential extraction in a soil with high carbonate content. Appl Geochem 21(1):16-28

Sutherland RA (2010) BCR ${ }^{\circledR}-701$ : a review of 10-years of sequential extraction analyses. Anal Chim Acta 680(1-2):10-20

Svensson BM, Mårtensson L, Mathiasson L, Eskilsson L (2005) Leachability testing of metallic wastes. Waste Manag Res 23(5):457-467

Tessier A, Campbell PGC, Bisson M (1979) Sequential extraction procedure for the speciation of particulate trace metals. Anal Chem 51(7):844-851

Yli-Halla M, Palko J (1987) Mineral element content of oats (Avena satina L.) in an acid sulphate soil area of Tupos village, Northern Finland. J Agric Sci Finland 59:73-78 
Young SD, Zhang M, Tye AM, Maxted A, Thums C, Thorton I (2005)

Characterizing the availability of metals in contaminated soils.

I. The solid phase: sequential extraction and isotopic dilution.

Soil Use Manag 21(s2):450-458
Zufiaurre R, Olivar A, Chamorro P, Nerín C, Callizo A (1998) Speciation of metals in sewage sludge for agricultural uses. Analyst 123(2):255-259 